\title{
Dimensions of entrepreneurial behaviour of handloom weavers in Thiruvanathapuram and Kannur districts
}

See end of the paper for authors' affiliations

\section{K. RARI JOHN}

Department of Home Science,

College of Agriculture, VELLAYANI (KERALA) INDIA

Email : rarijosephd@gmail.com
ABSTRACT : The study entitled dimensions of Entrepreneurial behaviour of Handloom Weavers of Thiruvanathapuram and Kannur district was undertaken with the objective to asses the entrepreneurial behaviour of the entrepreneur handloom weavers. Thiruvananthapuram (TVPM) and Kannur (KNR) districts of Kerala were purposively selected for conducting the study since the prominent handloom weaving clusters come under these districts. A sample of 150 entrepreneur weavers was selected each from both the districts, using stratified random sampling technique. Dimensions of entrepreneurial behaviour were assessed by using various scales developed by different authors and modified for this study. The results of the study revealed that the entrepreneurs had only medium risk taking ability and achievement motivation scores with medium production score. Majority of the respondents had medium planning, production and marketing orientation. The entrepreneurs have low income and resort to debt and they may fall short of aspirations. There was no significant difference in the dimensions of entrepreneurial behaviour between the respondents from TVPM district and KNR district.

KEY WORDS: Entrepreneur, Thiruvananthapuram, Kannur, Aspiration, Risk

- HOW TO CITE THIS PAPER : Rari John, K. and Kamini, S. (2015). Dimensions of entrepreneurial behaviour of handloom weavers in Thiruvanathapuram and Kannur districts. Asian J. Home Sci., 10 (2) : 424-431. 